\title{
Assessment of Potentially Toxic Elements in Egbetua Stream Sediments, South-Western Nigeria
}

\author{
S. O. Obaje
}

\section{ABSTRACT}

\begin{abstract}
The study area is located in Egbetua area in Akoko Edo Local Government Area of Edo State, southwestern Nigeria. the aim of the study is to assess the concentrations of potentially toxic elements in sediments from the study area. Ten samples collected from various locations in Egbetua stream were subjected to standard geochemical analysis using energy dispersive $x$-ray fluorescence spectrometer model "Minipal 4". The average concentrations of six elements are $\mathrm{V}(26.89 \mathrm{ppm}), \mathrm{Cr}(32.33 \mathrm{ppm})$, Co (6.13 ppm), Ni (16.10 ppm), Au (21.13 ppm), and $\mathrm{Zr}(1,285.20 \mathrm{ppm})$ and they were compared to those of upper continental crust baseline values. $\mathrm{V}, \mathrm{Cr}$, $\mathrm{Co}$, and $\mathrm{Ni}$ have extremely low concentrations, while $A u$ and $\mathrm{Zr}$ have very high concentrations. Moreover, $\mathrm{V}, \mathrm{Cr}, \mathrm{Co}$, and $\mathrm{Ni}$ have average enrichment ratios of $0.28,0.35,0.35$ and 0.34 , respectively, which are $<1$ implying their depletion in relation to their average crustal baseline concentrations. On the other hand, Au and $\mathrm{Zr}$ are highly enriched in the study area. Au has average geoaccumulation index (Igeo) values of 4.40 indicative of strongly to extremely polluted, while $\mathrm{Cr}, \mathrm{Co}, \mathrm{Ni}$ and $\mathrm{Zr}$ have average Igeo values of $10.95,6.14,9.98$ and 17.34 , respectively, indicative of sediments that are extremely polluted. The potentially toxic elements pose very serious environmental geochemical pollution threat in the study area. It is recommended that urgent action should be taken to mitigate and clean the study area of these potentially toxic elements.
\end{abstract}

Keywords: Geochemical analysis, Egbetua, Nigeria, potentially toxic elements.
Published Online: December 24, 2021

ISSN: $2684-446 \mathrm{X}$

DOI : $10.24018 /$ ejgeo.2021.2.6.225

\section{S. O. Obaje *}

Adekunle Ajasin University AkungbaAkoko, Nigeria.

(e-mail: solomon.obaje@aaua.edu.ng)

*Corresponding Author

\section{INTRODUCTION}

The study area is located in Egbetua area in Akoko Edo Local Government Area of Edo State, Southwestern Nigeria. It is located on latitudes $07^{\circ} 21^{\prime} 30^{\prime \prime} \mathrm{N}$ and $07^{\circ} 22^{\prime} \mathrm{N}$ longitudes $06^{\circ} 15^{\prime} 30^{\prime \prime} \mathrm{E}$ and $06^{\circ} 17^{\prime} \mathrm{E}$ and average elevation of 182 metres (Fig. 1). The aim of the study is to assess potentially toxic elements in Egbetua stream sediments. Trace element geochemistry of stream sediments is useful in determining concentration of potentially toxic elements in the environment [1]-[4]. Egbetua has rugged topography, and the drainage pattern is dendritic (Fig. 1). The area is accessible via untarred road, footpaths, and stream channels. Egbetua is a rural agricultural settlement, though there is presence of small-scale artisanal mining of river sand, dimension stones and gold. Though much has been published on the basement geology of the study area, there is extreme scarcity of published works on the geochemistry of stream sediments of the study area.

\section{A. Local Geology of the Study Area}

The study area belongs to the Igarra Schist belt which is within the crystalline Basement Complex rocks of the Southwestern Nigeria. The predominant rocks in the area are migmatite-gneiss-quartzite complex, schist, marbles, and porphyritic granites [5], [6].

\section{MATERIALS AND METHODS}

The materials used in the field during the collection of samples includes GPS, hammer, sample bags, field notebook, sampler, pen, pencil, masking tape, metre rule, funnel and set of sieves. The laboratory materials used are Energy Dispersive X-Ray Fluorescence (EDXRF) spectrometer of model "Minipal 4", oven, pulveriser, desiccators, pelletizer, and crucibles.

Samples of stream sediments were taken from ten locations in the study area. The geographic coordinates of sample locations were noted in the field notebook. The samples were wet sieved and conveyed in well labelled sample bags.

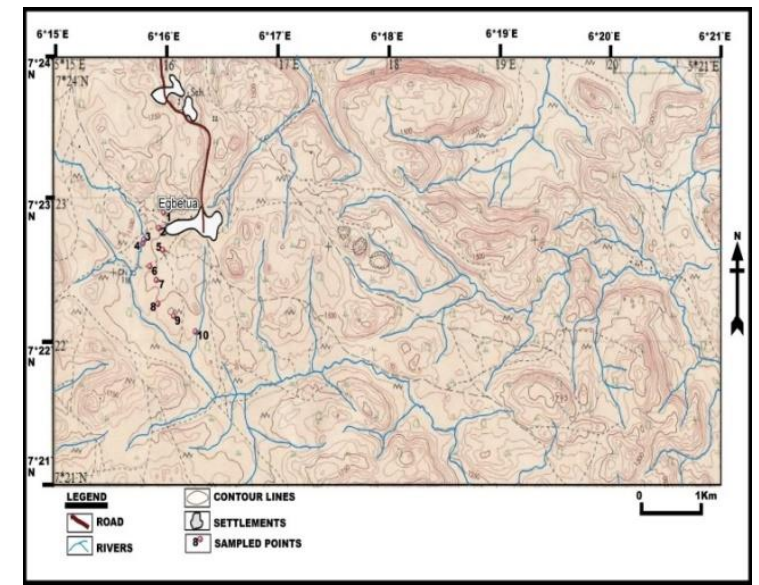

Fig. 1. Topographic map of the study area with sampling location (after FSN [7]) 
The samples were pulverised (milled into fine powder) using target pulverising machine (Planetary Micro Mill Pulverisette 7). $5 \mathrm{~g}$ of the pulverised sample was weighed into a beaker, $1 \mathrm{~g}$ of binding aid (Starch soluble). Homogeneity was achieved through thorough mixing of the sample with the binder together pressed under high pressure (6 tonnes") to make pellets for trace element analysis. Energy Dispersive XRay Fluorescence (EDXRF) spectrometer of model "Minipal 4 " was used for the analysis. The well labelled compressed pellets achieved under pressure of $1,500 \mathrm{Kgm}^{-2}$ were carefully placed in the various measuring positions on the machine.

\section{RESUlT AND DisCUSSION}

The elemental composition in parts per million (ppm) for $\mathrm{V}, \mathrm{Cr}, \mathrm{Co}, \mathrm{Ni}, \mathrm{Au}$ and $\mathrm{Zr}$ are given in Table I, while Fig. 2 shows the elemental compositions given in Table I as a histogram plot. The result of the six potentially toxic elements in the sediments from the study area are as follows: V (14.82 ppm - 43.32 ppm, average 26.89 ppm), Cr (16.64 ppm - $63.32 \mathrm{ppm}$, average $32.33 \mathrm{ppm})$, Co (3.00 ppm $12.34 \mathrm{ppm}$, average $6.13 \mathrm{ppm}), \mathrm{Ni}(4.51 \mathrm{ppm}-52.84 \mathrm{ppm}$, average $16.10 \mathrm{ppm}), \mathrm{Au}(11.47 \mathrm{ppm}-47.50 \mathrm{ppm}$, average of $21.13 \mathrm{ppm})$ and $\mathrm{Zr}(170.00 \mathrm{ppm}-3,180 \mathrm{ppm}$, average 1,285.20 ppm).

In Table II, the average concentrations of the six elements were compared to those of upper continental crust baseline values of Gao et al. [8], Taylor and McLennan [9]-[10], Wedepohol [11], Rudnick and Gao [12]. In comparison with the upper continental crust baseline concentration values of Rudnick and Gao [12], V, Cr, Co, and Ni have extremely low concentrations, while $\mathrm{Au}$ and $\mathrm{Zr}$ have very high concentrations.

Element enrichment ratios were calculated in order to assess the extent of enrichment and/or depletion of the trace elements in the study area. The enrichment ratios (ER) were calculated using the formula: $\mathrm{ER}=\mathrm{Cn} / \mathrm{Bn}$ where $\mathrm{Cn}$ is an element's concentration in the sample, while $\mathrm{Bn}$ is the background/baseline concentration of an element in known standard or average upper continental crustal concentration [12]. The upper continental crust concentrations of elements were taken as baseline and background values. ER $>1$ or $<1$ means enrichment or depletion of an element relative to average crustal concentration.
In Table 3, V, Cr, Co, Ni have average enrichment ratios of $0.28,0.35,0.35,0.34$, respectively, which are $<1$ implying their depletion in relation to their average crustal concentrations. On the other hand, Au and $\mathrm{Zr}$ have average ER of 14.09 and 6.66, respectively, indicative that $\mathrm{Au}$ and $\mathrm{Zr}$ are highly enriched in the study area. The abnomalous concentrations of $\mathrm{Au}$ and $\mathrm{Zr}$ are attributable to geogenic factors such as the $\mathrm{Au}$ mineralised schist and complete weathering of the source rocks of the study area.

Igeo is used to assess metal contamination in the sediments in line with Muller [13]. Igeo is computed using the formula:

$$
\operatorname{Igeo}=\log _{2}(\mathrm{Cn} / 1.5 \mathrm{Bn})
$$

where $\mathrm{Cn}$ is the measured concentration of an element in the sediments and $\mathrm{Bn}$ is the background/baseline concentration of an element in known standard or average upper continental crustal concentration [12]. In Table IV, the Igeo values range and average for the elements are as follows: V (9.90 ppm $11.45 \mathrm{ppm}$, average of $10.76 \mathrm{ppm}), \mathrm{Cr}$ (10.00 ppm $11.92 \mathrm{ppm}$, average of $10.95 \mathrm{ppm})$, Co $(5.11 \mathrm{ppm}-7.15 \mathrm{ppm}$, average of $6.14 \mathrm{ppm}), \mathrm{Ni}(7.14 \mathrm{ppm}-10.69 \mathrm{ppm}$, average of $8.98 \mathrm{ppm}), \mathrm{Au}(3.52-5.57 \mathrm{ppm}$, average of $4.40 \mathrm{ppm})$ and $\mathrm{Zr}$ (14.42 ppm - 18.64 ppm, average of 17.34). Au has Igeo values of 4.40 which fall within the Igeo class of 4-5 in Table $\mathrm{V}$, indicative of strongly to extremely polluted, while $\mathrm{Cr}, \mathrm{Co}$, $\mathrm{Ni}$ and $\mathrm{Zr}$ have average Igeo values of 10.95, 6.14, 9.98 and 17.34, respectively, which are $>5$ Igeo values of Table V, indicative that the sediments from the study area are extremely polluted with the elements. Consequently, V, Cr, $\mathrm{Co}, \mathrm{Ni}, \mathrm{Au}$ and $\mathrm{Zr}$ pose very serious environmental geochemical pollution threat in the study area.

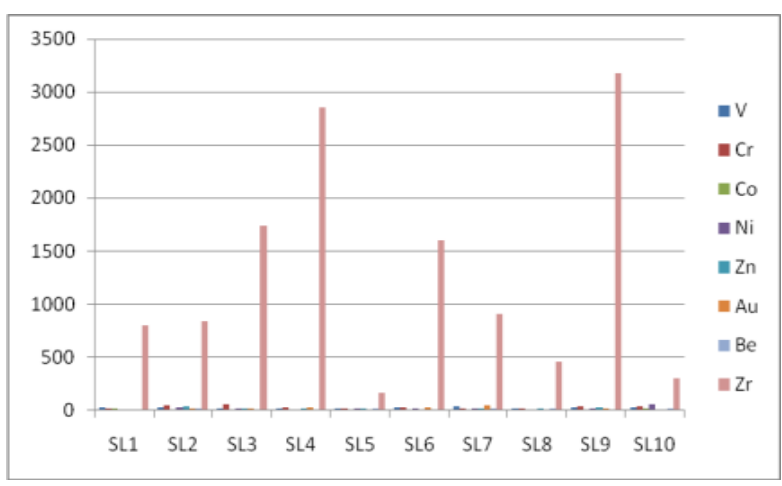

Fig. 2. Trace elements concentration in sediments from study area.

TABLE I: TRACE ELEMENT GEOCHEMICAL ANALYSIS OF SAMPLES FROM STUDY AREA (IN PPM)

\begin{tabular}{|c|c|c|c|c|c|c|c|c|c|c|c|c|c|}
\hline Element & SL1 & SL2 & SL3 & SL4 & SL5 & SL6 & SL7 & SL8 & SL9 & SL10 & Min & Max & Mean \\
\hline $\mathrm{V}$ & 31.92 & 27.16 & 14.82 & 22 & 17.71 & 32.82 & 43.32 & 24.18 & 28.42 & 26.54 & 14.82 & 43.32 & 26.89 \\
\hline $\mathrm{Cr}$ & 16.64 & 48.12 & 63.32 & 28.41 & 22.92 & 27.48 & 19.2 & 21.51 & 40.82 & 34.91 & 16.64 & 63.32 & 32.33 \\
\hline $\mathrm{Co}$ & 8.24 & 4.52 & 3.00 & 5.64 & 4.48 & 5.9 & 5.62 & 4.84 & 6.71 & 12.34 & 3.00 & 12.34 & 6.13 \\
\hline $\mathrm{Ni}$ & 4.51 & 21.6 & 12.42 & 9.26 & 13.58 & 9.46 & 18.5 & 7.14 & 11.65 & 52.84 & 4.51 & 52.84 & 16.10 \\
\hline $\mathrm{Au}$ & 12.31 & 18.63 & 23.4 & 25.38 & 11.93 & 24.65 & 47.5 & 11.47 & 23.4 & 12.63 & 11.47 & 47.50 & 21.13 \\
\hline $\mathrm{Zr}$ & 800 & 840 & 1738 & 2850 & 170 & 1600 & 910 & 463 & 3180 & 301 & 170 & 3180 & 1285.20 \\
\hline
\end{tabular}

TABLE II: RESUlT OF GEOCHEMICAL ANALYSIS OF SAMPLES WITH TRACE ELEMENTS IN COMPARISON TO PUBLISHED UPPER CRUST CONCENTRATIONS IN PPM (N=10)

\begin{tabular}{|c|c|c|c|c|c|c|c|}
\hline \multirow{2}{*}{ Element } & \multicolumn{3}{|c|}{ This Study } & \multicolumn{4}{|c|}{ Upper Continental Crust } \\
\hline & Min & Max & Mean & $\mathrm{A}$ & $\mathrm{B}$ & $\mathrm{C}$ & $\mathrm{D}$ \\
\hline $\mathrm{V}$ & 14.82 & 43.32 & 26.89 & 98.00 & 107.00 & 53.00 & 97.00 \\
\hline $\mathrm{Cr}$ & 16.64 & 63.32 & 32.33 & 80.00 & 85.00 & 35.00 & 92.00 \\
\hline Co & 3.00 & 12.34 & 6.13 & 17.00 & 17.00 & 12.00 & 17.30 \\
\hline $\mathrm{Ni}$ & 4.51 & 52.84 & 16.10 & 38.00 & 44.00 & 19.00 & 47.00 \\
\hline $\mathrm{Au}$ & 11.47 & 47.5 & 21.13 & 1.24 & 1.80 & - & 1.50 \\
\hline $\mathrm{Zr}$ & 170 & 3180 & 1285.20 & 188.00 & 190.00 & 237.00 & 193.00 \\
\hline
\end{tabular}

${ }^{\mathrm{A}}[8] ;{ }^{\mathrm{B}}[9],[10] ;{ }^{\mathrm{C}}[11] ;{ }^{\mathrm{D}}[12]-($ case study used). 
TABLE III: ENRICHMENT RATIOS FOR EGBETUA STREAM SEDIMENT

\begin{tabular}{cccc}
\multicolumn{4}{c}{ SAMPLES $(\mathrm{N}=10)$} \\
\hline Element & Min & Max & Mean \\
\hline $\mathrm{V}$ & 0.15 & 0.45 & 0.28 \\
$\mathrm{Cr}$ & 0.18 & 0.69 & 0.35 \\
$\mathrm{Co}$ & 0.17 & 0.71 & 0.35 \\
$\mathrm{Ni}$ & 0.10 & 1.12 & 0.34 \\
$\mathrm{Au}$ & 7.65 & 31.67 & 14.09 \\
$\mathrm{Zr}$ & 0.88 & 16.48 & 6.66 \\
\hline
\end{tabular}

TABLE IV: INDEX OF GEOACCUMULATION OF TRACE ELEMENTS IN EGBETUA STREAM SEDIMENTS ( $=10$ )

\begin{tabular}{cccc}
\hline Element & Min & Max & Mean \\
\hline $\mathrm{V}$ & 9.90 & 11.45 & 10.76 \\
$\mathrm{Cr}$ & 10.00 & 11.92 & 10.95 \\
$\mathrm{Co}$ & 5.11 & 7.15 & 6.14 \\
$\mathrm{Ni}$ & 7.14 & 10.69 & 8.98 \\
$\mathrm{Au}$ & 3.52 & 5.57 & 4.40 \\
$\mathrm{Zr}$ & 14.42 & 18.64 & 17.34 \\
\hline
\end{tabular}

TABLE V: CLASS INTERPRETATION OF INDEX OF GEOACCUMULATION OF TRACE ELEMENTS (AFTER MULLER [13])

\begin{tabular}{ccc}
\hline Igeo value & Igeo class & Pollution intensity \\
\hline$>5$ & 6 & Extremely polluted \\
$4-5$ & 5 & Strongly to extremely polluted \\
$3-4$ & 4 & Strongly polluted \\
$2-3$ & 3 & Moderately to strongly polluted \\
$1-2$ & 2 & Moderately polluted \\
$0-1$ & 1 & Unpolluted to moderately polluted \\
0 & 0 & Unpolluted \\
\hline
\end{tabular}

\section{CONCLUSION AND RECOMMENDATION}

Potentially toxic elements in the sediments from the study area have been analysed. Six of these elements analysed have the following concentrations in range and average values: $\mathrm{V}$ (14.82 ppm - $43.32 \mathrm{ppm}$, average $26.89 \mathrm{ppm}), \mathrm{Cr}$ (16.64 ppm - $63.32 \mathrm{ppm}$, average $32.33 \mathrm{ppm})$, Co (3.00 ppm $12.34 \mathrm{ppm}$, average $6.13 \mathrm{ppm})$, Ni (4.51 ppm - $52.84 \mathrm{ppm}$, average $16.10 \mathrm{ppm}), \mathrm{Au}(11.47 \mathrm{ppm}-47.50 \mathrm{ppm}$, average of $21.13 \mathrm{ppm})$ and $\mathrm{Zr}(170.00 \mathrm{ppm}-3,180 \mathrm{ppm}$, average $1,285.20 \mathrm{ppm})$.

The average concentrations of the six elements were compared to those of upper continental crust baseline values. In comparison with the upper continental crust baseline concentration values of Rudnick and Gao [12], V, Cr, Co, and $\mathrm{Ni}$ have extremely low concentrations, while $\mathrm{Au}$ and $\mathrm{Zr}$ have very high concentrations.

$\mathrm{V}, \mathrm{Cr}, \mathrm{Co}$, and $\mathrm{Ni}$ have average enrichment ratios of 0.28 , $0.35,0.35,0.34$, respectively, which are $<1$ implying their depletion in relation to their average crustal concentrations. On the other hand, Au and $\mathrm{Zr}$ have average ER of 14.09 and 6.66, respectively, indicative that $\mathrm{Au}$ and $\mathrm{Zr}$ are highly enriched in the study area. The abnomalous concentrations of $\mathrm{Au}$ and $\mathrm{Zr}$ are attributable to geogenic factors such as the $\mathrm{Au}$ mineralised schist and complete weathering of the source rocks of the study area.

According to Muller [13], Igeo values 4-5 indicate strongly to extremely polluted and Igeo values $>5$ indicate extremely polluted. Au has average Igeo values of 4.40 indicative of strongly to extremely polluted, while $\mathrm{Cr}, \mathrm{Co}, \mathrm{Ni}$ and $\mathrm{Zr}$ have average Igeo values of $10.95,6.14,9.98$ and 17.34, respectively, which are $>5$ Igeo values of Table V, indicative that the sediments from the study area are extremely polluted with the elements and they pose very serious environmental geochemical pollution threat in the study area.
It is recommended that urgent action should be taken to mitigate and clean the study area of these potentially toxic elements.

\section{ACKNOWLEDGMENT}

S. O. Author thanks Prof. O. E. Ige, the Vice Chancellor of Adekunle Ajasin University Akungba-Akoko, Ondo State, Nigeria for his support and encouragement.

\section{FUNDING}

The Author was self-sponsored.

\section{CONFLICT OF INTEREST}

The Author declares that he does not have any conflict of interest.

\section{REFERENCES}

[1] S. O. Obaje, A. I. Akpoborie, F. C. Ugbe. Heavy Metal Pollution Assessment of Sediments of River Gora in Minna, North-Central Nigeria: Statistical Approach. Journal of Environment and Earth Science, 2014;4(23):142-149.

[2] S. O. Obaje, A. C. Ogunyele, O. A. Adeola, A. S. Akingboye. Assessment of stream sediment pollution by potentially toxic elements in active mining area of Okpella, Edo State, Nigeria. The Mining Geology Petroleum Engineering Bulletin UDC, 2019;504:43-50. DOI: 10.17794/rgn.2019.2.5.

[3] S. O. Obaje. Granulometric and geochemical assessment of Ajali Sandstone in Fugar Area in Benin Flank of Anambra Basin, Nigeria. FULafia Journal of Science and Technology, 2019;5(2):78-87.

[4] S. O. Obaje, I. P. Adeniran. Textural characteristics of River Ogbagha sediments in Okpella Area, Southwest Nigeria. Science Research Annals, 2019; vol. 10 (Special Edition):136-147.

[5] I. B. Odeyemi. Lithostratigraphy and Structural Relationships of the Upper Precambrian Metasediments in Igarra area, Southwestern Nigeria. In Precambrian Geology of Nigeria, P. O. Oluyide, W. C. Mbonu, A. E. O. Ogezi, I. G. Egbuniwe, A. C. Ajibade, A. C Umeji, Eds. Geological Survey of Nigeria, Kaduna, 1988, pp. 111-125.

[6] A. C. Ogunyele, S. O. Obaje, A. S. Akingboye. Lithostructural Relationships and Petrogenetic Affinities of the Basement Complex Rocks around Okpella, Southwestern Nigeria. Earth Sciences Malaysia (ESMY), 2018;2(1):29-36. DOI: http://doi.org/10.26480/esmy.01.2018.29.36.

[7] FSN (Federal Survey of Nigeria), Topographical Map, Auchi Sheet 264, Nigeria, 1964.

[8] S. Gao, T. C. Luo, B. R. Zhang, H. F. Zhang, Y. W. Han, Y. K. Hu, Z. D. Zhao. Chemical composition of the continental crust as revealed by studies in East China, Geochim. Cosmochim. Acta, 1975;62:19591975.

[9] S. R. Taylor, S. M. McLennan. The continental crust: Its composition and evolution. Blackwell, Oxford, 1985.

[10] S. R. Taylor, S. M. McLennan. The geochemical evolution of the continental crust. Rev. Geophys., 1995;33:241-265.

[11] K. H. Wedepohl. The composition of the continental crust. Geochimica et Cosmochimica Acta, 1995;59:1217-1232.

[12] R. L. Rudnick, S. Gao. Composition of the continental crust. In The Crust 3, R. L. Rudnick, Ed. in Treatise on Geochemistry, Holland, H. D. and K. K. Turekian, Eds., Elsevier-Pergamon, Oxford, 2003, pp. 164.

[13] G. Muller. Index of Geoaccumulation in sediments of the Rhine River. Geology Journal, 1969;2:108-118.

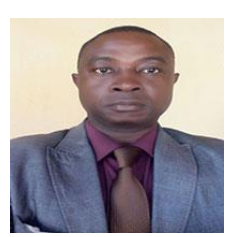

Dr. Solomon Omale Obaje has several published research articles in refereed, peer-reviewed, reputed main-stream national and international journals. He is widely travelled and a regular presenter of research papers in local, national, and international conferences and workshops. He has passion for geology, Information Technology and human leadership. He has 
European Journal of Environment and Earth Sciences

www.ej-geo.org

more than seventeen years experience in research. He is a member of several professional bodies such the Nigerian Mining and Geosciences Society, Nigerian Association of Petroleum Explorationists, Nigerian Computer Society, etc. He is a registered geoscientist with the Council of Mining Engineers and Geoscientists and Computer Professional Registration Council. Dr. Solomon Omale Obaje obtained the United Africa Company of Nigeria (U.A.C.N.) post-primary school scholarship award for his secondary school education. He is also a recipient of the Nigerian Federal Government Post Graduate Fellowship award for his M.Sc. Geology degree studies at the reputed Ahmadu Bello University, Zaria, Kaduna State, Nigeria. He is also a recipient of the FME/World Bank STEP-B Ph.D. Grant and the CGGVeritas-NAPE Grant-in-Aid award for Ph.D. Geology research at the prestigious Federal University of Technology, Minna, Niger State, Nigeria. $\mathrm{He}$ is presently an Associate Professor of Geology and former Acting Head of Department of Earth Sciences, Faculty of Science, Adekunle Ajasin University Akungba-Akoko, Nigeria. Dr. Solomon O. Obaje is happily married and blessed with children. 